\title{
原著論文
}

\section{歯の欠損状態と咀嚼筋活性との関連性に ついての筋電図学的研究}

\author{
井上 俊二西塔 治 石井 弘二 石垣 尚一 \\ 奥田 畺夫 中村 隆志 赤西 正光 丸山 剛郎
}

\section{Relationships between Tooth Loss and Electromyographic Activities of Masticatory Muscles}

Shunji Inoue, Osamu Saito, Hiroji Ishii, Shouichi Ishigaki, Tadao Okuda, Takashi Nakamura, Masamitsu Akanishi and Takao Maruyama

\begin{abstract}
For purpose of evaluating the characteristic of electromyographic activities of masticatory muscles with front or molar tooth loss, electromyographic activities of masticatory muscles and mandibular movements during tooth tapping and gum chewing were investigated in each group of tooth loss, and were compared with those of control group. The results were as follows.

1. In reference to the group with front tooth loss,

1) On tooth tapping, each S.D. of the time parameters of electromyographic activities of jaw closing muscles especially masseter and posterior temporalis was small, and that of jaw opening muscle was large.

2) On gum chewing, offset of jaw closing muscles' activities especially masseter and anterior temporalis were delayed.

3) On both tooth tapping and gum chewing, there was no difference in mandibular movements from control group.

2. In reference to the group with molar tooth loss,

1) On both tooth tapping and gum chewing, each S.D. of the time parameters of electro. myographic activities of jaw closing muscles was large.

2) On tooth tapping, S.D. of opening ratio was large.

3) On gum chewing, both S.D. of chewing cycle and opening ratio were large.
\end{abstract}

Key words : tooth loss, masticatory muscles, electromyographic activities

大阪大学歯学部歯科補経学第一講座

Fast Department of Prosthetic Dentistry Osaka University

Faculty of Dentistry

平成元年 3 月 29 日受付

\section{I. 緒 言}

頼口腔機能は歯, 額関節, 笳肉の 3 要素とそれらを統 
合する上位中枢よりなるいわゆる機能的咬合系の調和の もとに営まれており, 機能的咬合系の各要素の 1 つでも 変化が生じれば, 他の構成要素と相互に影響しあい, そ の順応の可否により, あるものは適応し，またあるもの は顎口腔機能に異常を生じる可能性がある.

機能的咬合系の一要素である歯に注目すれば，大きく 前歯部と曰歯部とに分けられ，これらは䪽口腔の重要な 機能の 1 つである一連の咀鮙行為中において, 咬断機能 は前歯, 臼磨機能は臼歯によるところが大きく, その役 割に相違があることは明らかである.

このため, 機能的咬合系のなかの歯と筋肉に着目し, 咀嚼運動を通して歯の欠損状態と咀嚼筋の活動状態との 関連性を知ることは, 広く顎口腔機能の状態を把握する 上できわめて重要なことであるといえる.

本研究は, 前歯部, 刍歯部の各欠損状態に対応する咀 嚼筋活動の特徴を捉えることを目的として，タッピング 運動およびガム咀徱における各欠損者群の咀嚼筋 活動 の, 主として時間的要素に関して分析を行ったものであ る.

\section{II. 研究方法}

\section{1. 被験者}

被験者は大阪大学歯学部附属病院第 1 補緅科に来院し た患者で, 前歯部欠損者群 (以下A群とする) として, 前歯部のみに欠損を有する患者のうち，上顎の両側の左 右中切歯を含む 4 歯以上の欠損を有する者, 男性 1 名, 女性 2 名, 計 3 名 (平均年齢 41 歳), 臼歯部欠損者群 (以 下P群とする）として，臼歯部のみに久損を有する患者 のうち，両側の上㖽あるいは下㖽の第 1 および第 2 大臼 㧘を含む欠損を有する者, 男性 2 名, 女性 1 名, 計 3 名 (平均年齡 55.3 歳) を選択した（表 1). 対照群 (以下 C 群とする) として, 本学歯学部学生および教職員のうち 自覚的, 他覚的に䫑口腔系に異常を認めず, 上下頡第 2 大臼歯をでを有する個性正常咬合者 6 名を抽出した。

\section{2. 実験方法}

被験者は歯科用治療椅子に頭部を固定せずに座らせ た.タッピング運動は, 毎分 60,80,120, 180 回の各頻 度別に行わせ, さらに被験食品としてガム 1 枚 (ロッテ 社製, フリーソ゚ーン）を用いてあらかじめ十分咀礵, 軟 化させた後, 咀嚼側を右側に指定して咀罚運動を行わせ た.

被験筋は閉口筋として右側咬筋浅層中央部，側頭筋前
表 1 欠損者群の粠成

\begin{tabular}{|c|c|c|c|c|}
\hline & subject & age & sex & missing teeth \\
\hline \multirow{3}{*}{ A group } & YMM & 54 & male & $21 \mid 123$ \\
\hline & YKM & 42 & female & \begin{tabular}{l|l|ll}
2 & 1 & 12 \\
\end{tabular} \\
\hline & TSJ & 27 & female & \begin{tabular}{ll|lll}
3 & 1 & 1 & 2 & 3 \\
\end{tabular} \\
\hline \multirow{5}{*}{$\mathrm{P}$ group } & \multirow{2}{*}{ ISI } & \multirow{2}{*}{58} & \multirow{2}{*}{ male } & $765 \quad 4567$ \\
\hline & & & & \begin{tabular}{l|}
5 \\
5
\end{tabular} \\
\hline & HRD & 57 & male & 7651 \\
\hline & TMR & 51 & female & 765 \\
\hline & & & & 67 \\
\hline
\end{tabular}

部，側頭筇後部，開口筋として右側顎二腹笳前腹を用い た.

筋電図は直径 $8 \mathrm{~mm}$ の表面電極 (日本光電社製小型生 体電極 NT-211 U) を用いて電極間距離 $8 \mathrm{~mm}$, 電極間抵 抗 $10 \mathrm{k} \Omega$ 以下の条件で双極誘導し, 生体アンプ（日本光 電社製生体アンプ RB-5) により増幅したのちデータレ コーダー（TEAC 社製 R-81）を用いて磁気テープに記 録した.

下顎運動は, 下䅡切歯点の前頭面的運動をサホンビ ジートレーナーCII（佐藤医療電子社製）を用いて同時 に記録した. タッピング運動時には, 右側煩骨部に貼付 したマイクロホンにより咬合音も同時に記録した.

\section{3. 計測項目}

データはオシロペーパー上に再生し計測を行った.タ ッピング運動は各頻度についてタッピング開始後 2 ス卜 ローク目から 11 ストローク目まで，ガム咀霹は 1 スト ローク目から10ストローク目までの，ともに10ストロ ークを計測の対象とした。

計測項目として筋電図はタッピング運動，ガム咀嚼と もに下䫅運動の閉口初期的を基準として，各ストローク 中の 4 筋の放電開始点 (以下開始点と略す), 放電終了点 (以下終了点と略す)，持続時間を計測した．下顎運動は， タッピング運動, ガム咀嚼とむに開口量を求めたが，各 被験者間でその絶対值が異なるため, 10 ストローク中の 最大の開口量を 1 とした際の各ストロークの開口量の比 率に換算した. またガム咀喘では，1 分間の咀噮回数 (以

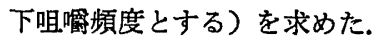

\section{4. 分析項目}

分析は各被験者毎に 10 ストロークの計測值の平均值 と標準偏差を求め, 各被験者群内での平均值の平均值, 

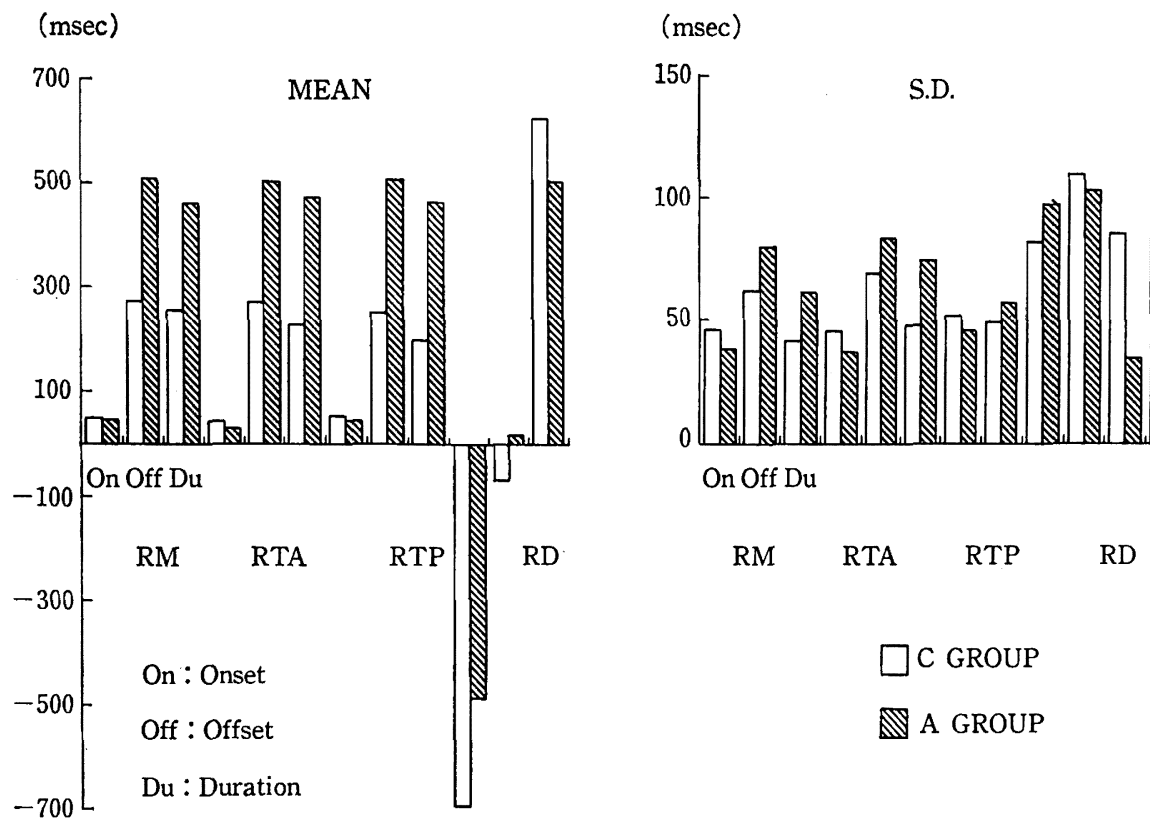

図 1 筋電図パラメータに関する $\mathrm{C}$ 群と A 群の比較 (タッピング 60/分)
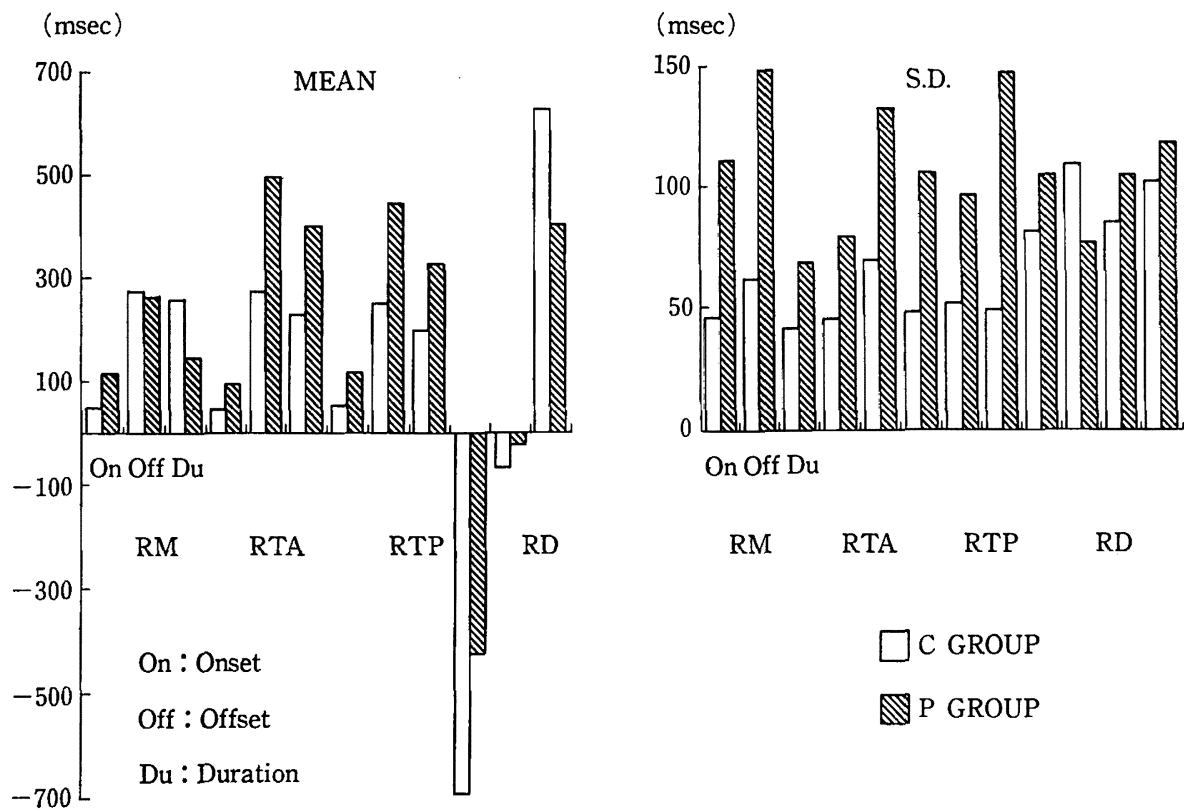

図 2 筋電図パラメータに関する C 群と $\mathrm{P}$ 群の比較 (タッピング 60/分)

標準偏差の平均值をもとに，各群間での筋活動および頭 運動のパラメータについて比較を行った.このうち開口 量の比率は, 各被験者内での相対値であるため, 標準偏 差についてのみ分析を行った. 筋活動についてはさらに 各久損者群内で, 被験者間における久損歯の相違との関
連性についても比較検討を行った.

な掠, 各比較群間の分析結果についてはそれぞれ $\mathrm{t}$ 検 定を行い，有意差を認めたものについて図表中に示した $(\mathrm{p}<0.05)$. 

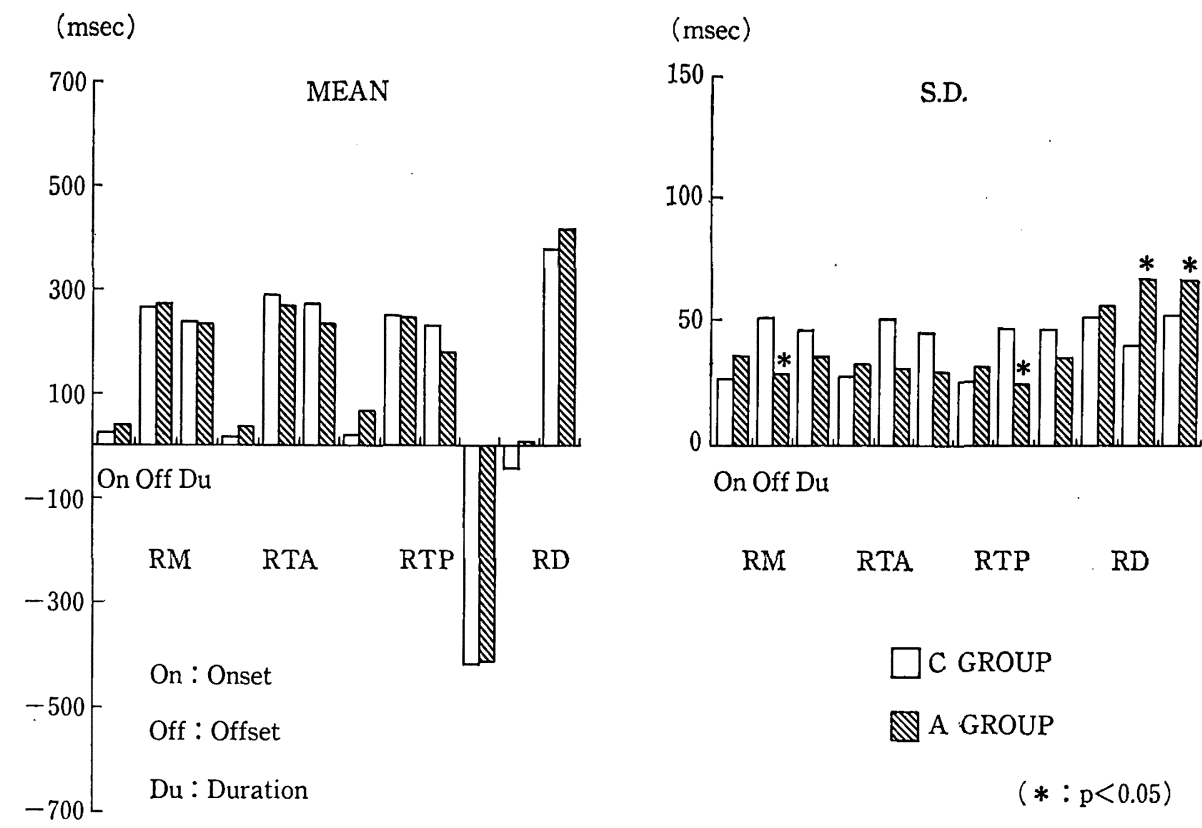

図 3 筋電図パラメータに関する C 群と A 群の比較 (タッピング 80/分)

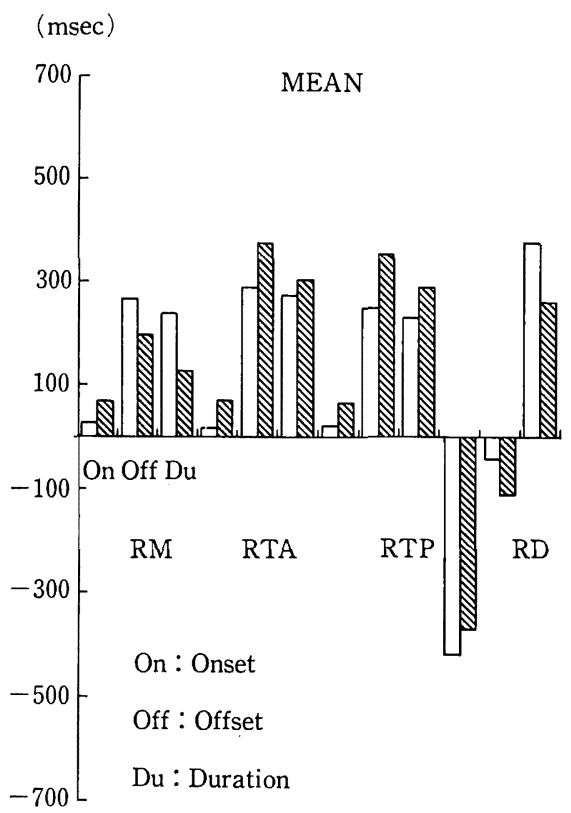

(msec)

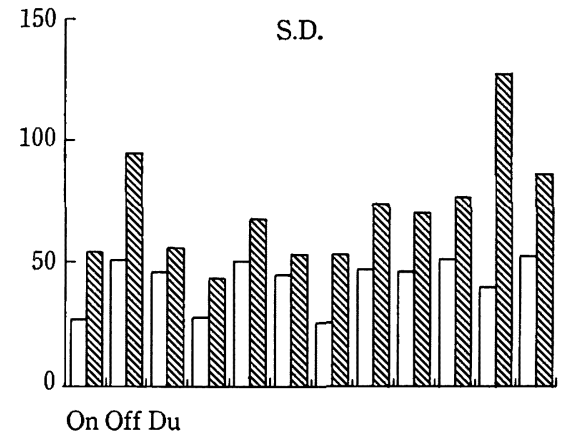

RM RTA RTP RD

図 4 筋電図パラメータに関する C 群と P 群の比較 (タッピング 80/分)

\section{III. 結 果}

1. 筋活動のタイミング

1) タッピング運動
(1) 毎分 60 回

毎分 60 回のタッピング運動時の $\mathrm{C}$ 群と A 群, $\mathrm{C}$ 群と $\mathrm{P}$ 群について比較した結果を各々図 1,2 に示す.

$\mathrm{A}$ 群は, 平均值では $\mathrm{C}$ 群と比較して閉口筋の終了点が 遅れ，持続時間がやや延長する傾向がみられたが，とも 

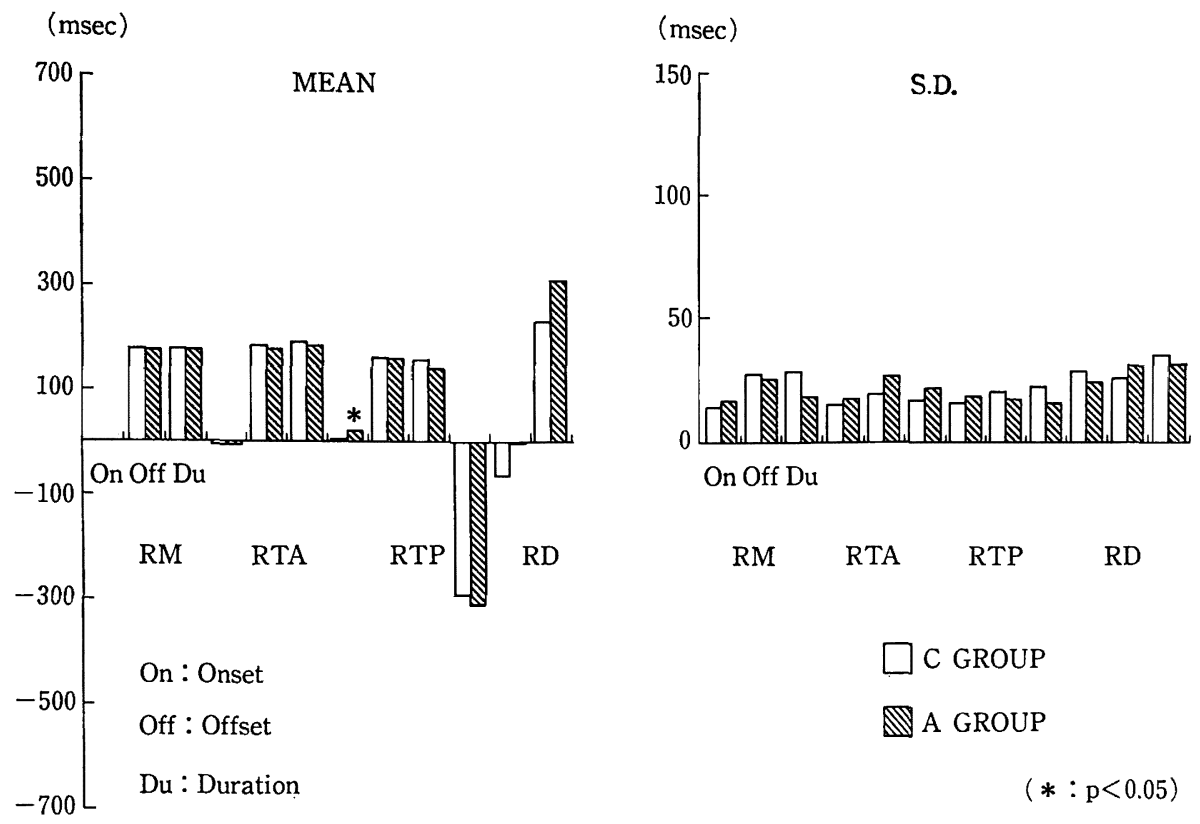

図 5 筋電図パラメータに関する $\mathrm{C}$ 群と $\mathrm{A}$ 群の比較 (タッピング 120/分)
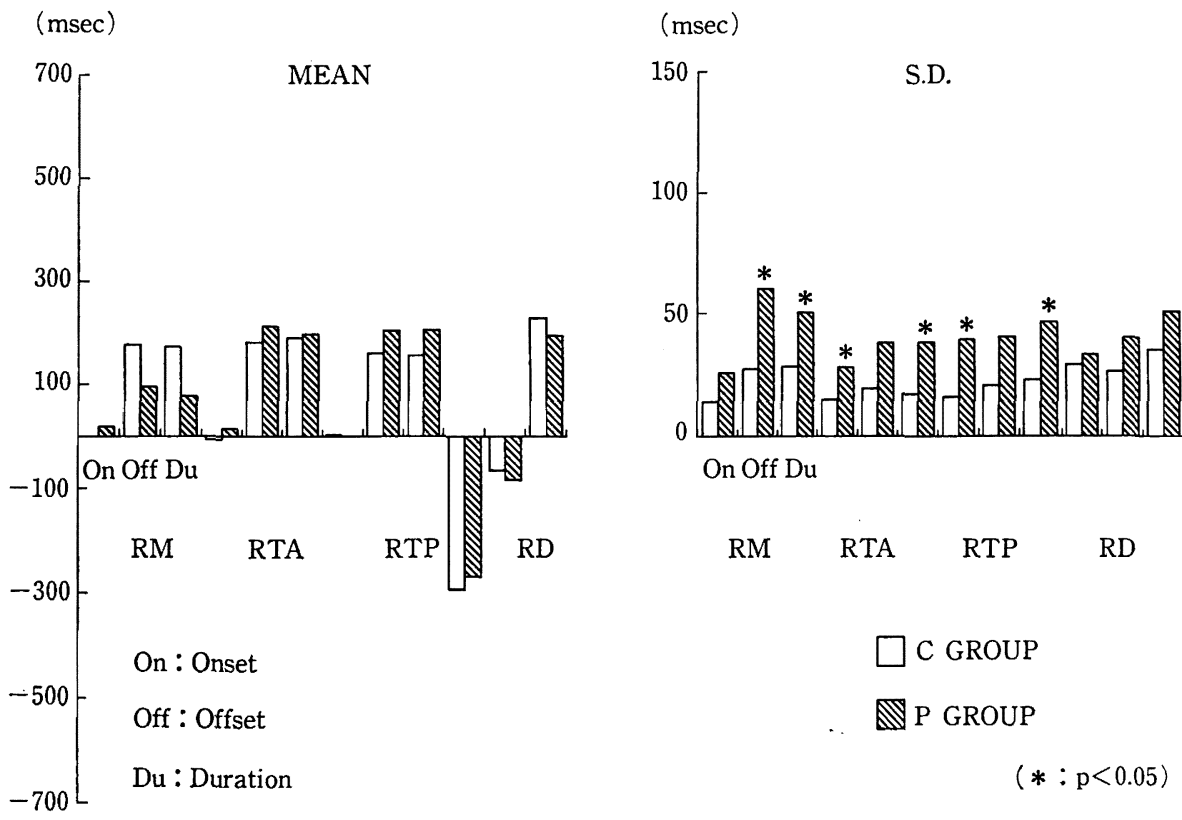

図 6 筋電図パラメータに関する C 群と P 群の比較 (タッピング 120/分)

に有意差は認めなかった，標準偏差は閉口筋，開口筋と もに各パラメータに有意差は認めなかった.

$\mathrm{P}$ 群は，平均值では閉口筋，開口筋ともに有意差を認 めなかった． 標隻偏差は閉口筋すべてのパラメータにっ いてバラッキの大きい傾向がみられたが，有意差は認め
なかった.

(2) 毎分 80 回 毎分 80 回の結果を図 3, 4 に示す.

$\mathrm{A}$ 群は, 平均値では C 群と比較して有意差を認めなか った. 標準偏差は, 閉口筋の終了点と持続時間のバラッ 

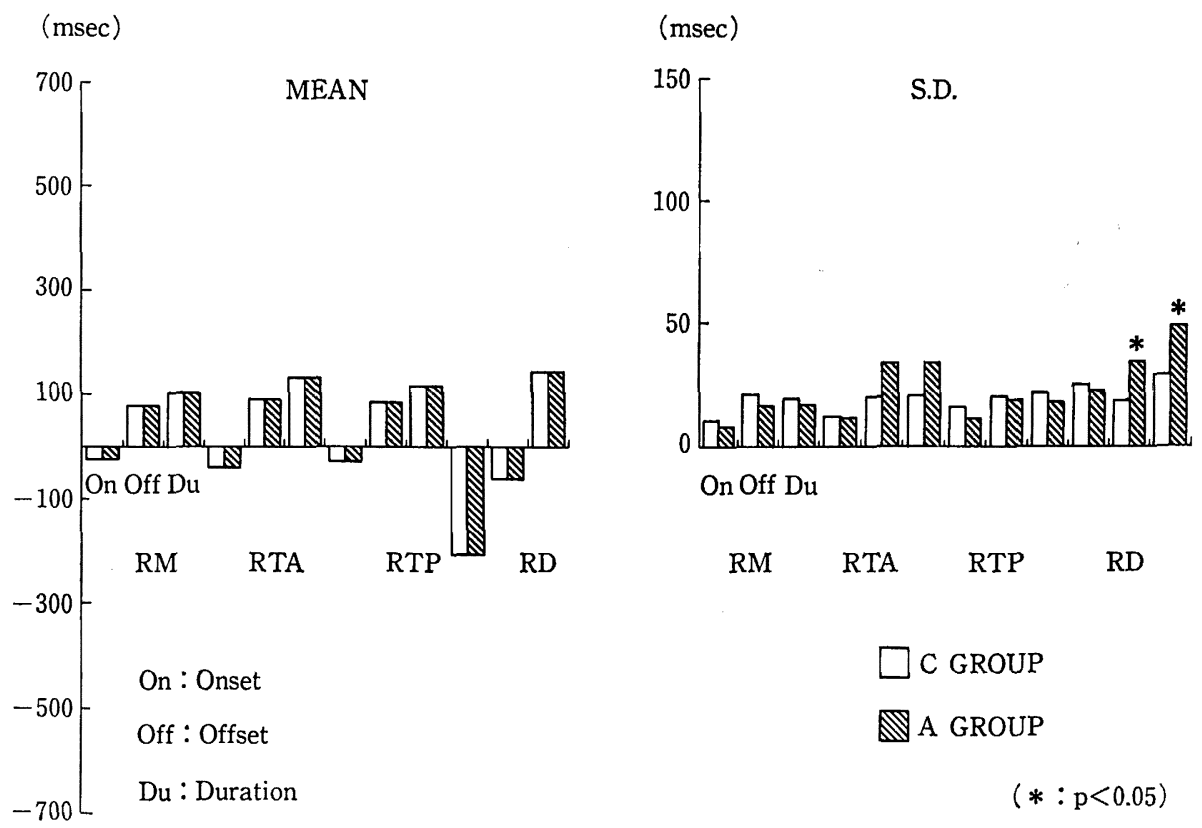

図 7 筋電図パラメータに関する C 群と A 群の比較 (タッピング 180/分)
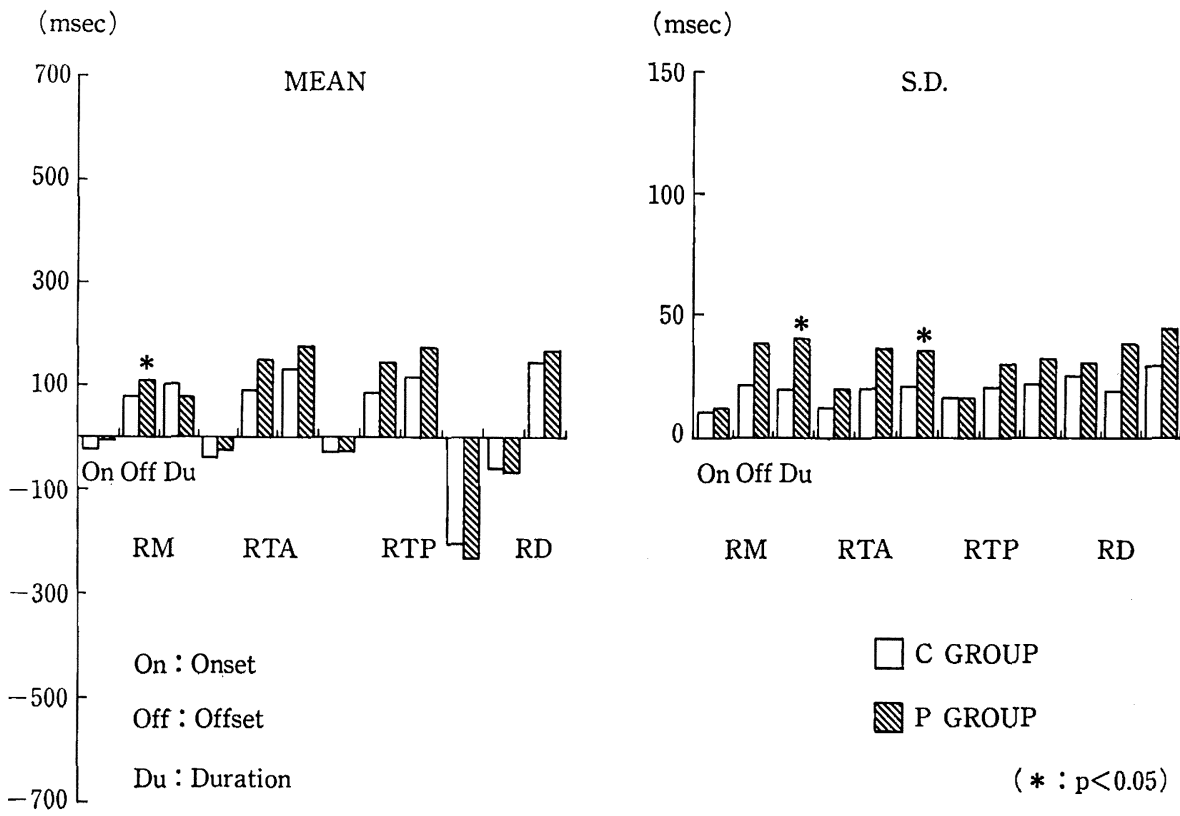

図 8 筋電図パラメータに関する C 群と $\mathrm{P}$ 群の比較 (タッピング 180/分)

キの小さい傾向がみられ，特に咬筋と側頭筋後部の終了 点については有意差を認めた．開口筋である顎二腹筋前 腹では, 終了点, 持続時間のバラッキが有意に大きい傾 向を認めた。

$\mathrm{P}$ 群は, 平均值では閉口筋，開口筋ともに有意差を恝
めなかった．標準偏差は閉口筋，開口筋ともにすべての パラメータについてバラッキの大きい傾向がみられた が，有意差は認めなかった。

（3）毎分 120 回

毎分 120 回の結果を図 5,6 に示す. 

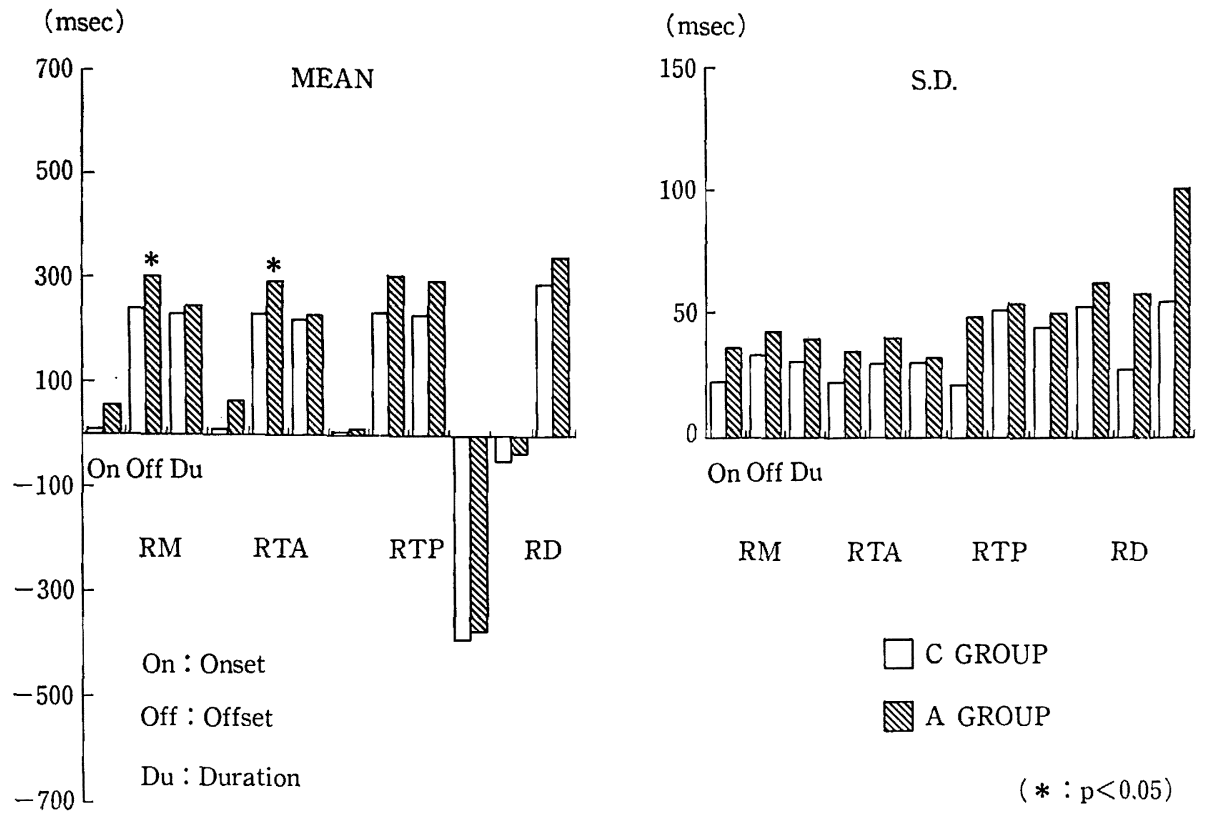

RM RTA RTP RD

図 9 笳電図パラメータに関する C 群と A 群の比較 (右側咀嚼)
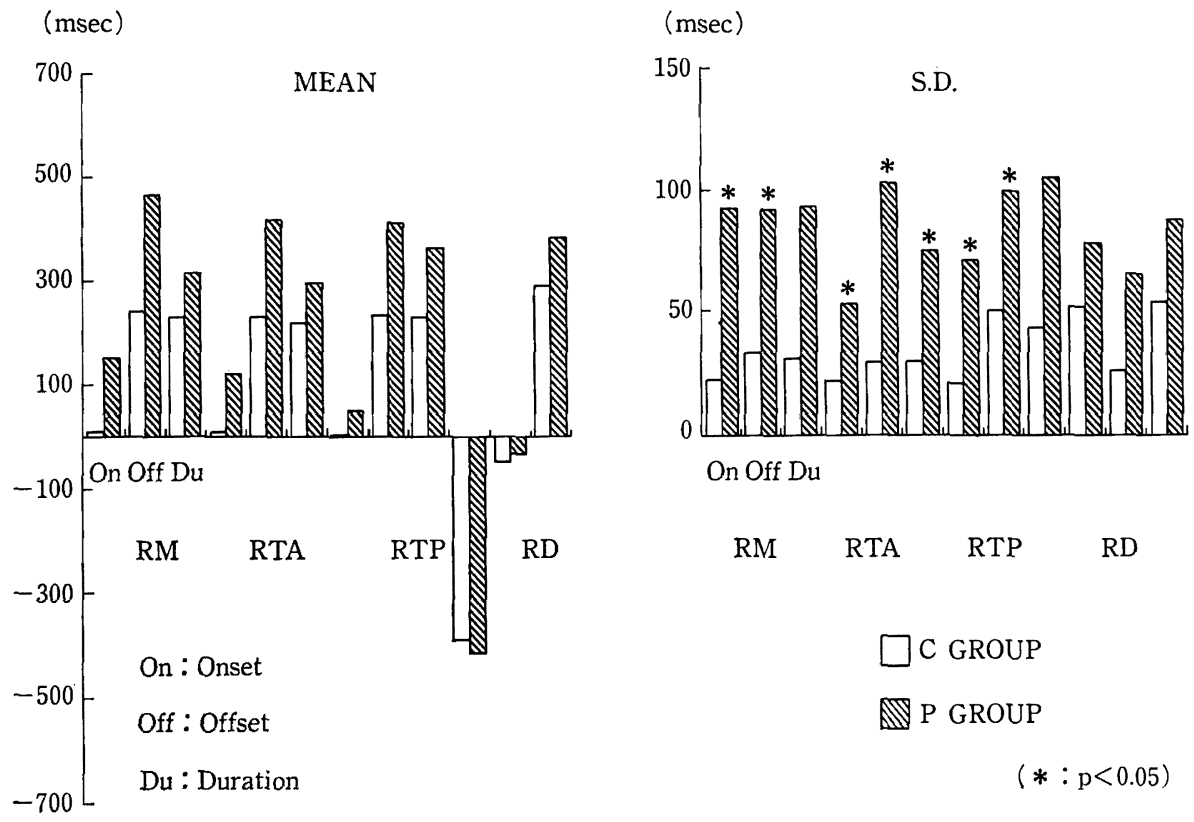

図 10 筋電図パラメータに関する C 群と $\mathrm{P}$ 群の比較 (右側咀獣)

$\mathrm{A}$ 群は，平均值では C 群と比較して閉口筋である側頭 筋後部の開始点が有意に遅れる傾向を認めたが，その他 のパラメータについては差を認めなかった。標準偏差は 閉口筋，開口筋ともに差を認めず，とりわ汀咬筋，側頭 筋後部はバラツキが小さかった.
$\mathrm{P}$ 群は, 平均値では閉口筋, 開口筋ともに有意差を認 めなかった．標準偏差は閉口筋，開口筋ともにどのパラ メータについてもバラッキの大きい傾向がみられ, 特に 閉口筋である咬筋の終了点と持続時間, 側頭筋前部, 側 頭筋後部の開始点と持続時間については有意差を認め 
表 2 被験者間で S.D. がより大であるパラメータ (A 群)

\begin{tabular}{|c|c|c|c|c|}
\hline \multirow{2}{*}{$\operatorname{contact} \frac{3}{3}$} & \multirow{2}{*}{ condition } & \multicolumn{3}{|c|}{ parameter } \\
\hline & & $\mathrm{RM}$ & RTA & RTP \\
\hline+ & $\begin{array}{l}\text { tapping } \\
60 / \mathrm{min} \\
\text { tapping } \\
180 / \mathrm{min}\end{array}$ & & duration & $\begin{array}{l}\text { offset } \\
\text { duration }\end{array}$ \\
\hline- & $\begin{array}{l}\text { tapping } \\
80 / \mathrm{min} \\
\text { right side } \\
\text { chewing }\end{array}$ & offset* & & duration \\
\hline
\end{tabular}

た.

(4) 毎分 180 回

毎分 180 回の結果を図 7, 8 に示寸.

$\mathrm{A}$ 群は, 平均值では $\mathrm{C}$ 群と比較して閉口笳, 開口筋と もに差を認めなかった．標準偏差は閉口管，とりわけ咬 筋，側頭笳後部のバラッキが小さく，開口筋である䫊二 腹筋前腹の終了点と持続時間のバラッキが有意に大きい 傾向を認めた。

$\mathrm{P}$ 群は，平均値では閉口筋，特に咬筋の終了点が有意 に遅れる傾向がみられたが，その他のパラメータに有意 差は認めなかった，標準偏差は，閉口筋，開口筋ともに 終了点と持続時間のバラッキの大きい傾向がみられ, 特 に閉口筋である咬筋と側頭筋前部の持続時間については 有意差を認めた。

2) ガム咀滞

ガム咀嚼の結果を図 9,10 に示す.

$\mathrm{A}$ 群は平均值では C 群と比較して閉口筋，特に咬筋と 側頭筋前部の終了点が有意に遅れる傾向を認めた．咬筋 と側頭筋前部の開始点についてもやや遅れる傾向がみら れたが，有意差は認めなかった，標準偏差については各 筋ともに差を認めなかった。

$\mathrm{P}$ 群は，平均値では閉口筋すべてのパラメータの值の やや大きい傾向がみられたが，ともに有意差を認めなか った．標準偏差は閉口筋すべてのパラメータについてバ ラツキの大きい傾向がみられ，特に閉口筋すべての開始 点と終了点, 側頭筋前部では持続時間についても有意差 を認め, 咀緭時に閉口筋活動のタイミングが不安定であ った.

3）各欠損者群内での欠損歯の相違による比較

(1) 前歯部欠損者群

$\mathrm{A}$ 群の被験者をさらに咀嚼側である右側の上下顎犬歯
33 巻 5 号 (1989)

表 3 被験者間で S.D. がより大であるパラメータ ( $\mathrm{P}$ 群)

\begin{tabular}{c|c|c|c|c}
\hline \multirow{2}{*}{ contact } & \multirow{2}{*}{ condition } & \multicolumn{3}{|c}{ parameter } \\
\cline { 3 - 5 } & & RM & RTA & RTP \\
\hline+ & & & & \\
\hline & $\begin{array}{c}\text { tapping } \\
80 / \text { min } \\
\text { right side } \\
\text { chewing }\end{array}$ & offset & $\begin{array}{l}\text { offset* } \\
\text { duration* } \\
\text { onset* } \\
\text { offset }\end{array}$ & \\
\hline
\end{tabular}

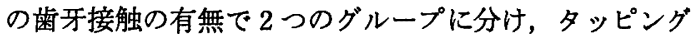
運動時およびガム咀嚼時で, 閉口筋の筋電図分析項目の うち標準偏差に関し，2群間で一方がより大きな值を示 した項目の中で, その差が対照群の被験者間での標準偏 差の標準偏差よりも大きかったものについて久損状態と の比較を行った，その結果を表 2 に示す．上下顎犬歯に 歯牙接触のない被験者では，ガム咀嚼時に咬筋の終了点 がばらつく傾向を認めた.

(2) 兒歯部欠損者群

$\mathrm{P}$ 群の被験者をさらに左側の上下頡第 1 および第 2 小 臼歯の歯牙接触の有無で 2 グループに分け, 同様に欠損 状態との比較を行った. その結果を表 3 に示す. 歯牙接 触のない被験者では, タッピング運動については各頻度 において一定した傾向はみられなかったが，ガム咀嚼時 においては側頭筋前部の開始点がばらつく傾向を認め た.

\section{2. 下顎運動}

各頻度のタッピング運動とガム咀嚼における開口量の 比率，およびガム咀嚼時の咀嚼頻度についての結果を図 11,12 に示す.

A 群は開口量の比率, ガム咀嚼の頻度ともにC 群と比 較して有意差を認めなかった.

$\mathrm{P}$ 群は，開口量の比率ではタッピング運動時，ガム咀 鮁時ともにバラツキの大きい傾向がみられ，特に毎分 80,120 回のタッピング運動時では有意差を認めた.ガ ム咀嚼の頻度では有意差涩認めなかったものの, バラッ キがやや大きかった.

\section{IV. 考 察}

\section{1. 被験者について}

藤井 ${ }^{1}$ ( $($ 健常有歯頜者と対咬関係を失った少数歯残 存 患者のタッピング運動時の下頒運動を記録し，健常者と 
開口量の比率

咀嚼頻度

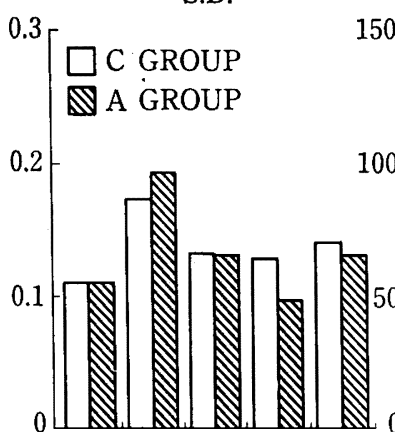

CHEW $180 \quad 120 \quad 80 \quad 60$
S.D.

MEAN

S.D.

図 11 下顥運動に関する C 群と A 群の比較

咀嘅頻度:

S.D.

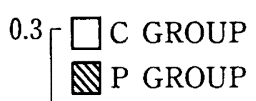

0.2

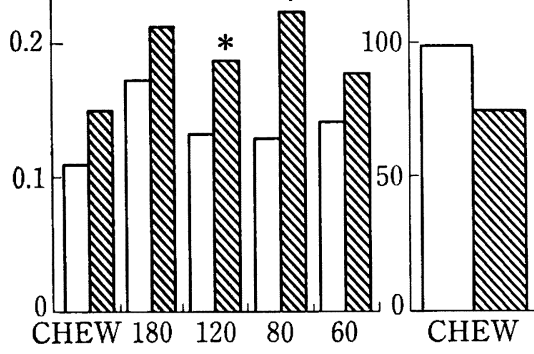

図 12 下瀕運動に関する $\mathrm{C}$ 群と $\mathrm{P}$ 群の比較

满足した義歯を装着していた患者の義歯撤去時の記録と の間には類似点が多く，長期間義歯を使用していない少 数歯残存患者の運動では, タッピング回数が少なく不安 定であることを示した. また Kayser2), Aukes ら²は臼 歯欠損による歯列の縮小が，咀嚼能率の低下や食品の性 状に関する嗜好に影響を与える可能性を示唆している. したがって, 歯の欠損者を用いた実験を行う場合, 被験 者の歯の欠損に至るまでの病歴や, 義歯使用状況など補 緅処置の経過が実験結果に影響を与える可能性が考えら れる.

本実験に用いた被験者は，その欠損部位の相違により， 歯の欠損に至るまでの経過に特徴がみられた．前歯部欠 損者群は，外傷や比較的限局した急性的な歯周疾患によ り短期間のうちに久損に至った被験者から構成されてお り，最終補緅に先だって暫間義歯使用中の者がほとんど
であったが欠損期間は短く，一方臼歯部欠損者群は，被 蝕および慢性的な歯周疾患により歯を失った被験者から 構成され，欠損期間は長いがその間は義歯を継続的に使 用しており，現在は最終補緅を終えた者がほとんどであ った.

したがって本研究では欠損者群間で，機能の経時的な 適応変化の程度に差が含まれている可能性も考えられ， この要素と咀嚼筋活動との関連性についても今後検討す る必要があろう。

歯の欠損状態についても各欠損者群により特徴がみら

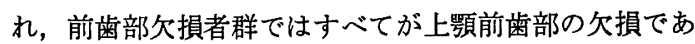
り，中でも欠損部位が犬歯にまで及ぶか否かの相違がみ られた． 臼歯部欠損者群では左右側で欠損がともに上顎 の者, 下顎にも及ぶ者, 一側は上蕦で一側は下顎の者と 様々で，欠損部位が右側では第 2 小田歯から第 2 大臼歯 までと共通していたが，左側では欠損が小臼歯にまで至 るか否かで相違がみられた。

欠損歯の相違により，各群内の被験者間においても筋 活動状態に差をみる可能性が考えられたため，特に閉口 筋の筋活動についてはさらに各欠損者群内で，被験者間 における久損歯の相違との関連性についても比較検討を 行った.

\section{2. 研究方法について}

1）被験筋について

いわゆる咀嚼筇と呼ばれる筋群の中で, 咬筋と側頭筋 は咬合の主導筋として広く筋電図学的研究の中に取りあ げられてきており，両者はその機能に関して比較され， 種々の検討がなされてきた. その中で側頭筋については, いくつかの報告で咬合の安定性に関与する可能性が示唆 され4 7), 通常, その特徴である広範な筋の走行から, 大 きく前部と後部とに分けて研究されている. 下影運動は 閉口筋群と開口筋群の筋活動の密接なつながりのもとに 営まれると考えられる. 三浦8) はこの両筋群が機能的に 異なった分化をしていると述べ，また河野9ははタッピン グ運動時にバイトブロックで片側の咬合を挙上した際の 筋活動持続時間を計測し, 咬筋および側頭筋では対照群 より短縮したが顎二腹筋では延長したと報告しており， 実験条件の変化に伴って閉口筋と開口筋とが一部に異な った反応を示す可能性を示唆している.

本実験では被験者として前歯部および臼歯部欠損者群 という，前後的な歯の欠損状態の相違に着目したことを 考虑して, 被験筋の選択にあたっては, 矢状面的な笳活 動の分析を行う目的で, 閉口筋として咀嚼側である右側 
の咬筋，側頭筋前部，側頭筋後部，開口筋として右側の 顎二腹筇前腹の 4 筋を用いた.

2) 計測項目について

本研究では筋電図の分析は時間的パラメータに関して 行った. 筋電図の時間的パラメータの分析を行ら場合, 通常その基準として歯牙接触点帛, 10), あるいは silent period $^{8)}$ 等を用いるのが一般的であり，タッピング運動 においては頻度の変化に対する閉口筋の筋放電持続時間 の対応の仕方がこの基準点の前後で異なるといった 報 告8,9)も多い. しかし，本実験では，各種下頻運動の時間 的経過の中で各咀覆筋相互の活動時期の関係について知 ることを目的としており，この関係を各々の閉口筋につ いて, さらに閉口筋群と開口筋群とについて比較検討し ようとするものであるため, 時間的基準点として閉口運 動の初期点を設定し, 時間的パラメータとして放電開始 点, 終了点, 持続時間を用いたことはより本研究の目的 に適していると考える.

\section{3. 結果について}

1）筋活動のタイミングについて

(1) タッピング運動について

$\mathrm{A}$ 群はC 群と比較すると平均値においては閉口筋, 開 口筋ともに筋活動のタイミングに差はみられず，標準偏 差に関しても閉口筋のバラッキに明かな差はみられなか った. このことは臼歯の残存によって咬頭嵌合位の安定 性が確保されていたために, タッピング運動のような下 顎の基本的な開閉運動に対しては大きな変化を生じなか ったためと考えられる.これに対し，標準偏差に関して は，毎分 80 回および 180 回の頻度において，開口筋で ある顎二腹笳前腹の終了点と持続時間のバラッキの大き い傾向がみられた. 毎分 60 回および 120 回の頻度にお いてこの傾向が見出せなかった理由は明らかではない が，三浦8) は正常者のタッピング運動において咬筋筋活 動の時間的要素は比較的高頻度において安定したと報告 しており，その点, 本研究で毎分 180 回の高頻度におい て開口筋の時間的パラメータのバラッキが大きかったこ とについては見過ごすべきではなかろう，この閉口筋と 開口筋の活動の安定性の相違に関しては, 前歯部におけ る歯牙感覚の有無との関連性も推察され，さらに詳細な 分析が必要である.

$\mathrm{P}$ 群は平均值に関しては一定の傾向を見出だせなかっ たが，標準偏差では C 群と比較して毎分 120 回および 180 回の頻度について閉口筋の各パラメータのバラッキ が大きかった．毎分 60 回および 80 回の頻度で差がみら
れなかったことに関しては先に述へた通り，低頻度のタ ッピング運動におおる不安定性が両群の差を打ち消した ためであろうが, 高頻度のタッピング運動におけるこの 結果は, 臼歯部欠損により, 安定したタッピング運動を 行う上で最も重要な条件の 1 つである咬頭嵌合位の安定 性が欠如したためであると考えられる.

(2) ガム咀嚼について

$\mathrm{A}$ 群は平均值では, $\mathrm{C}$ 群と比較して閉口筋のうち咬筋 と側頭筋前部の終了点の遅れる傾向がみられた. これは 両筋の開始点が有意差はなかったもののC 群に比べやや 遅れていたことと考え合わせると, 前歯部欠損者群では 咬管と側頭筋前部の活動時期に遅れを生じたとも考えら れる. 三浦 ${ }^{11}$, 中村ら ${ }^{12)}$ 多くの研究にみられるように下 䇗の水平的な運動においては咬筋は前方位で, 側頭筋後 部は後方位あるいは側方位の移動側において明瞭な筋活 動を示し, 側頭筋前部についてはその機能的意義と動態 において両者の中間的ともいうべき態度を示すといわれ ている. また河野ら $\left.{ }^{13}\right)$ は，偏心位での咬みしめにおいて は咬筋および側頭筋は前後的な下頢の位置変化との関連 が强く，咬筋は前方位で，側頭筋後部は後方位での咬み しめにおいて明瞭な笳活性を示すと述へている. これら の所見を参考にすれば, 前歯部欠損者群にみられるこの 筋活動の特徴は，閉口運動の初期において後方あるいは 側方への要素が強調されるため, 比較的前方への作用成 分の強い咬筋と側頭筋前部の活動時期に遅れを生じたも のとも考えられる. 仮にそうであるとすれば，歯列上に おける食塊の位置と使われる歯の役割, すなわち咀壪運 動において咬断運動よりも慨運動の傾向が強まるから ではないかとの見方もできる．しかしながら一方で，前 歯部欠損に起因する咬合誘導の変化といった因子も無視 できない.この点に関しては前頭面あるいは水平面的な 咀嚼経路の分析, 筋活性に関する分析および咬合様式等 を含めた詳細な検討が必要であろう。

$\mathrm{P}$ 群では平均值に関しては一定の傾向を見出せなかっ たが，標淮偏差はC 群と比較して閉口筋すへての時間的 パラメータのバラッキが大きかった. このことはタッピ ング運動と同様に臼歯部欠損に起因した咬頭嵌合位の安 定性の欠如による影響がガム咀嚼においても反映してい るためであると考えられる。

（3）ガム咀嚼とタッピング運動との比較

咀嚼頻度の平均值をみると A 群では毎分 75 回, $\mathrm{P}$ 群 では毎分 74 回であったので, A 群, P 群ともにガム咀嚼 を毎分 80 回のタッピング運動と比較した.

$\mathrm{A}$ 群は平均值ではタッピング運動と異なり，閉口筋で 
ある咬筋と側頭管前部の終了点がC 群と比較して遅れる 傾向がみられた. このことは咀擸運動がタッピング運動 と異なって，片側上下歯列間に食塊を介在した偏心位に おける下額運動を伴うことが関係しているといえる．閉 口時, とりわけ閉口初期にはタッピング運動と異なり下 顎は側方一偏位し，それに引き続いて前内方へと引き戻 される. 前歯部欠損者ではこの閉口時の下䫟運動経路の 変化が強調されるために，前方への作用成分の強い咬管 と側頭笳前部の活動終了時期が遅れるものと考えられ る.

$\mathrm{P}$ 群は標準偏差ではタッピング運動と同様に，閉口筋 の各時間的パラメータのバラッキがC群と比較して大き い傾向がみられたが，特にガム咀嚼時ではタッピング運 動に比べその傾向がより著明であった. このことは大日 歯の咬合接触関係の欠如が，とりわけ咀嚼の閉口相およ び咬合相に大きく関与しているものと考える.

（4）各欠損者群内での欠損歯の相違による比較 前歯部欠損者群では，上下頷犬歯に歯牙接触のない被 験者において，ガム咀嚼時に咬笳の終了点のばらつく傾 向がみられた。一般に咬頭嵌合位の位置うけよりもむし ろ側方運動に大きく関与すると考えられている犬歯の歯 牙接触の欠如が，咬合力の主導䈘とみなされている咬管 の活動 ${ }^{14,15)}$ にのみ影響を与えているとは考えにくく，よ

り被験者数を増して検討を加える必要があろう.

日歯部欠損者群では左側の上下䫟第 1 および第 2 小曰 菌の歯牙接触のない被験者で，ガム咀嚼時に側頭筋前部 の開始点のばらつく傾向がみられた. Greenfield ら4), Ramfjord ら ${ }^{5)}$, Bohl ら ${ }^{6)}$ の研究にみられるように, 側頭 筋前部に関しては下滪運動の安定性に関与するとの見解 が多い.このことから先の結果については，咬頭嵌合位 での両側臼歯の歯牙接触状態の不均衡が，咀㘉時の咬合 相付近において側頭筋前部の筋活動に影響を及ぼしたた めではないかとも考えられる。

2）下顥運動について

(1) タッピング運動について

開口量の比率の標準偏差に関して $\mathrm{A}$ 群では C 群と比較 して差はみられなかったが， $\mathrm{P}$ 群ではC 群と比較して各 瀕度においてバラッキが大きかった.このことは筋活動 の項で述べたように苗部欠損による咬頭嵌合位の安定 性の欠如が大きく関与しているものと考えられ，閉口筋 の筋活動にみられた閉口運動の不安定性が開口相にも影 帮を及ぼしたことがうかがわれる，またこの結果から， $\mathrm{P}$ 群においては開口筋である影二腹管前腹の筋活動の夕 イミングのバラッキについてもC 群と比較して大きくな
ってもよい筈であるが，今回の実験では有意差はみられ なかった. この点に関しても，今後被験者数を増して検 討を加えればさらに明らかになるであろう.

(2) ガム咀嚼について

$\mathrm{A}$ 群はC 群と比較してどのパラメータについても差は みられなかったが， $\mathrm{P}$ 群では有意差は認めなかったもの の開口量の比率，咀嚼周期ともにバラッキがやや大きか った. Atkinson ら ${ }^{16)}$ は歯の欠損により咬合支持を失っ

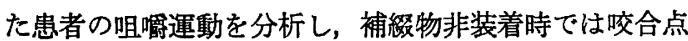
が一定しないと報告している．したがってこの点につい てもタッピング運動と同様の理由が考えられ，咀嚼時に 閉口筋活動のタイミングが不安定であったこととの関連 性がうかがわれた。

\section{V. 結 論}

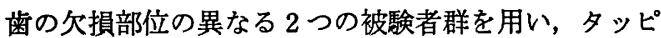

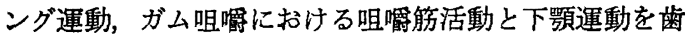
の欠損のない対照群と比較した結果，以下の結論を得 た.

前歯部欠損者群では対照群と比較して,

1. タッピング運動時に閉口筋，特に咬笳，側頭筋後 部の筋活動のタイミングのバラッキが小さく，開口筋の バラツキの大きくなる傾向が認められた.

2. ガム咀礵時に閉口筋, 特に咬筋, 側頭筋前部の筋 活動終了時間の遅くなる傾向が認められた.

3. タッピング運動時, ガム咀嚼時の箩運動には特に 差は認められなかった。

臼歯部欠損者群では対照群と比較して,

4. タッピング運動時，ガム咀嚼時ともに閉口筋すべ ての筋活動のタイミングのバラッキの大きくなる傾向が 認められた。

5. タッピング運動時の開口量のバラッキの大きくな る傾向が認められた。

6. ガム咀嚼時の咀嚼頻度および開口量のバラッキの 大きい傾向がみられた.

\section{文献}

1）藤井弘之: 少数齒残存症例の類筋機能, Dental Diamond, $10: 18 \sim 23,1985$.

2) Kayser, A.F. : Shortened dental arches and oral function, J Oral Rehabil, $8: 457 \sim 462,1981$.

3) Aukes, J.N.S.C., Kayser, A.F. and Felling, A.J.A. : The 
subjective experience of mastication in subjects with shortened dental arches, J Oral Rehabil, $15: 321 \sim 324$, 1988.

4) Greenfield, B.E. and Wyke, B.D. : Electromyographic studies of some muscle of mastication, Br Dent J, 100 : $129 \sim 143,1956$.

5) Ramfjord, S.P. and Ash, M.M. : Occlusion, 5 6, W.B. Saunders, Philadelphia, 1966.

6) Bohl, C.F. and Knap, F.J. : Evaluating occlusal relationships, mandibular dysfunction, and temporomandibular joint by palpation, J Prosthet Dent, $32: 80 \sim 86,1974$.

7）鈴木伸宏 : 咬合力と咀嚼筋の筋放電との関係についての実 験的研究一第 1 報咬合点の前後的変化について, 歯科学報, $84: 253 \sim 300,1984$.

8）三浦周太郎：タッピング運動時の咬筋活動に関する筋電図 学的研究, 補緅誌, $30: 247 \sim 260,1986$.

9）河野正勝：咬合挙上とリズムの変化が EMG の時間的要素 一及ぼす影響について, 日大歯学, $55: 434 \sim 447,1981$.
10) Ahlgren, J.: Kinesiology of the mandible. An EMG study, Acta Odontol Scand, $25: 593 \sim 611,1967$.

11）三浦不二夫 : 笳電図法による咀雨筋の活動様式に関する研 究 (特に咬筋, 側頭筋, 澦二腹筋について), 口病誌, 23 : 25 54, 1950.

12）中村隆志, 赤西正光, 丸山剛郎ほか: 下颌側方運動におけ る顎筋筋活動に関する研究, 日本額関節学会雑誌, $1: 1$ 8, 1989.

13）河野正司, 坂東永一, 田中伐平ほか：咀緭筋の筋活動を指 標とした咬合位の推定, 補緅誌, $26: 1271 \sim 1286,1982$.

14) Ahlgren, J. : Mechanism of mastication, Acta Odontol Scand, 24, Suppl. $44: 1 \sim 109,1966$.

15) Dubner, R., Sessle, B.J. and Storey, A.T. : The neural basis of oral and facial function. Plenum, N.Y. : 317 321, 1978.

16) Atkinson, H.F. : Masticatory movement in the absence of teeth in man, Arch Oral Biol, $18: 855 \sim 860,1973$. 